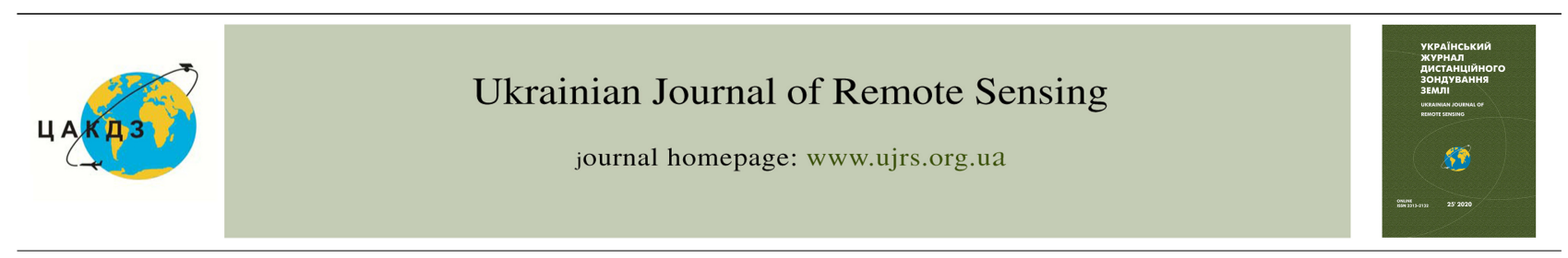

DOI: $10.36023 /$ ujrs.2020.25.173

УДК 553.981/982/477,5/8/

\title{
Comprehensive approach in definition of the oil and gas exploration objects priority
}

\author{
A. Mychak, A. Shybetska * \\ Scientific Centre for Aerospace Research of the Earth, National Academy of Sciences of Ukraine, 5B O.Gonchar st., \\ Kyiv 01054, Ukraine
}

JSC "Ukrnafta" is the main oil producing company which carries out explorative drilling in the Dnipro-Donetsk's and PreCarpathian basins. The decrease in number of seismic studies negatively affects discovery of new potential hydrocarbon bearing structures. Reliability and productivity of seismic surveys influences productivity of explorative drillings. The article analyzes the results of seismic surveys, data from case studies and geochemical surveys to predict the oil and gas prospective areas in the Dnipro-Donetsk basin, as well as their complexation. It is shown that need to use alternative methods of exploration has objectively been increasing, in particular - use of remote methods for determining the presence of hydrocarbons (using space images). To create predictive geological structural models based on a selected set of studies are widely used modern software products for reserves and resources estimation with statistical probabilistic approaches and associated risk computation functionalities. Comprehensive study of results carried out in previous years, utilization of modern methods and software for data analysis enables to define directions of geological exploration works for the following years in order to raise its efficiency and strengthen the reserves base.

Keywords: prospective structures, exploration works, case studies, comprehensive approach, remote sensing, seismic survey

(C) A. Mychak, A. Shybetska. 2020

\section{Introduction}

Exploratory drilling provides discovery of new fields and the growth of hydrocarbon reserves, which is very important for independent Ukraine. The drilling footage depends on the amount of funding and the availability of perspective exploration sites. The number of objects, in turn, depends on the results of comprehensive geological and geophysical studies.

The decrease in number of conducted seismic surveys and case studies in recent decades negatively affects the replenishment of the new potential structures with new objects suitable for planning of exploration works. It also affects the movement of objects: from the discovery stage, through the stages of delineation to the stages of drilling and experimental development planning.

\section{Purpose of the article}

The purpose of this article is to give an analysis of results of study of works that are classically executed in order to set up exploratory drilling in oil and gas industry companies. Based on such analysis are proposed ways to increase the effectiveness of current solution for tasks mentioned above with the application of a rational set of geological, geophysical and case studies. To achieve this goal, the results of practical application of various methods of searching for prospective structures are considered: - seismic exploration works;

- case studies;

- geochemical;

- remote sensing methods.

\footnotetext{
*E-mail: AShybetska@gmail.com

Тел.: +3809528757 78
}

\section{Seismic exploration works}

The main sources for replenishment of the prospective structures are seismic surveys. Decrease in number of regional seismic exploration works leads to lack of new structures suitable for exploration works, e. g. objects that could be source of new fields (Goshovsky et al., 2007; annual Naftogaz of Ukraine report).

Recent seismic exploration works did not reveal anticlinal structures of significant size. As a rule, objects for 1-2 wells are not economically attractive. The lithological objects offered for exploration works as a separate hydrocarbon traps, were mostly not confirmed by the results of drilling. Thus, the expediency of prospecting works for many lithological objects of the Chernihiv oil and gas industry district (Skhidno-Khukalovskyi, Perevolochnianskyi, Kvytnevyi, etc.) remains uncertain, as indicated by the lack of interest in them by mining enterprises and finding in the fund of the discovered objects of the State Geological Survey. (Online map of prospects). The same applies to tectonically sealed traps (Goshovsky et al., 2007; Okrepka et al., 2016).

In addition, the accuracy of geological constructions based on seismic survey results has certain limitations, which lead to "migration" of the location of the apical parts of structures and structures themselves in time (Southern Panasovskaya, Khukhrinskaya deposit, Ivanovskaya area etc.). The issue of the correspondence of seismic constructions with the results of drilling remains unanswered. This determines the need for monitoring of seismic objects.

The complexity of obtaining unambiguous results (Zakhidno-Wilshaya area) in the study of highly perspective areas close to salt diapirs (Starosanjarsky, Novosanzharsky-Pereshchepinsky, 
Gasenkivski salt structures) requires additional case studies and their application in the interpretation and re-interpretation of field seismic exploration works (Goshovsky et al., 2007; Tovstyuk 1987).

Use the latest software to reinterpret seismic materials from the last century has already become a good practice. It rises the prognosis for not only structures, but also, sometimes, hydrocarbon reservoirs.

In Ukraine 3D seismic surveys are rarely used on field exploration phase, although for foreign investors the State Department of Geodesy has prepared investment projects, which are proposed to be submitted competitively in 2019 on electronic bid platform and which already requires $3 \mathrm{D}$ seismic surveys on exploration stage.

\section{Case studies}

Equally important are case studies, which are based on analysis and developed methodological techniques and determine perspective places of accumulation and storage of hydrocarbons. Unfortunately, state owned company UkrDGRI which was leading in this respect is almost non-functioning. Due to lack of funding, its regional offices are closed. Case studies in some places had a purely scientific focus and could not be applied for forecasting the presence of hydrocarbon reservoirs and positioning of new wells. In other words, the authors cited research findings but did not provide criteria that could be used for prediction. In addition, the cost-effectiveness of drilling at the proposed sites was not considered due to the high cost of the wells.

Assistance to mining companies was offered by many developers of methods of direct search for hydrocarbon accumulations. But, unfortunately, most of them did not have statistically reliable confirmations, or had them for objects with more simple structure of other oil and gas areas, that is they were not adapted to the conditions of the Dnieper Donetsk Basin (DDB) and PreCarpathian Basin.

In 1990-2019 PJSC "Ukrnafta" actively used various kinds of different scientific approaches for definition of new objects, contours of hydrocarbon deposits for production of prospecting drilling that was stated many times in various articles and reports. List of such methods includes biolocation, geochemical, electrophysical, dense, spectrometric remote aerospace and other types of case studies (Okrepka et al., 2016; Shybetska et al., 2008).

Company experience has shown the complexity of simultaneous use of different methods for the same object, that was resulted in some contradictions within the results of research. The contours of the detected anomalies mostly did not coincide (Khukhra-Chernechenskaya area, Prokopenki, Verbivskyi, Orlivska area etc.) and the drilling results were often negative. On figures Fig. 1, 2, 3 research results are shown in format of map, where structures and fault blocks are visualized together with contours of detected hydrogeological and geochemical anomalies.

According to some results of researches within the facilities,

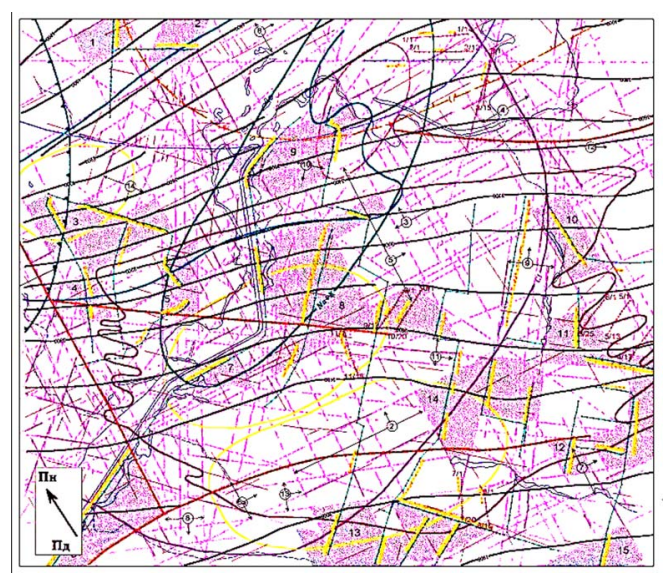

Fig. 1. Scheme of oil and gas prospects position according to results of geological, geochemical, geophysical and case studies on Orlivska area (Pererva at all, 1999). Faults are marked with: red lines - results of geophysical studies, pink lines - faults originated from airborne images and geomorphology study. Colored lines indicate hydrogeological anomalies. Pink areas indicate possible oil and gas prospects

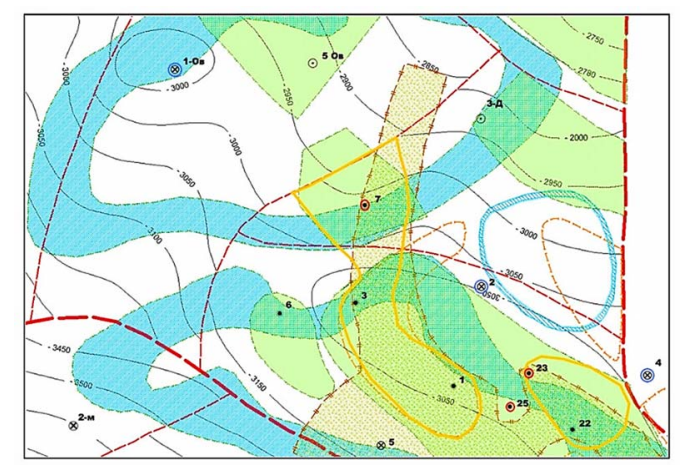

Fig. 2. Scheme of case study results on Khukhra-Chernecha area (according to Arkhipov et al., 1999). Red dotted line on picture indicates faults of seismic studies origin, yellow lines — facies analysis anomalies, thick blue lines — positive gas anomalies, thin blue line — negative gas anomalies. Light green areas - anomalies defined using remote sensing methods 


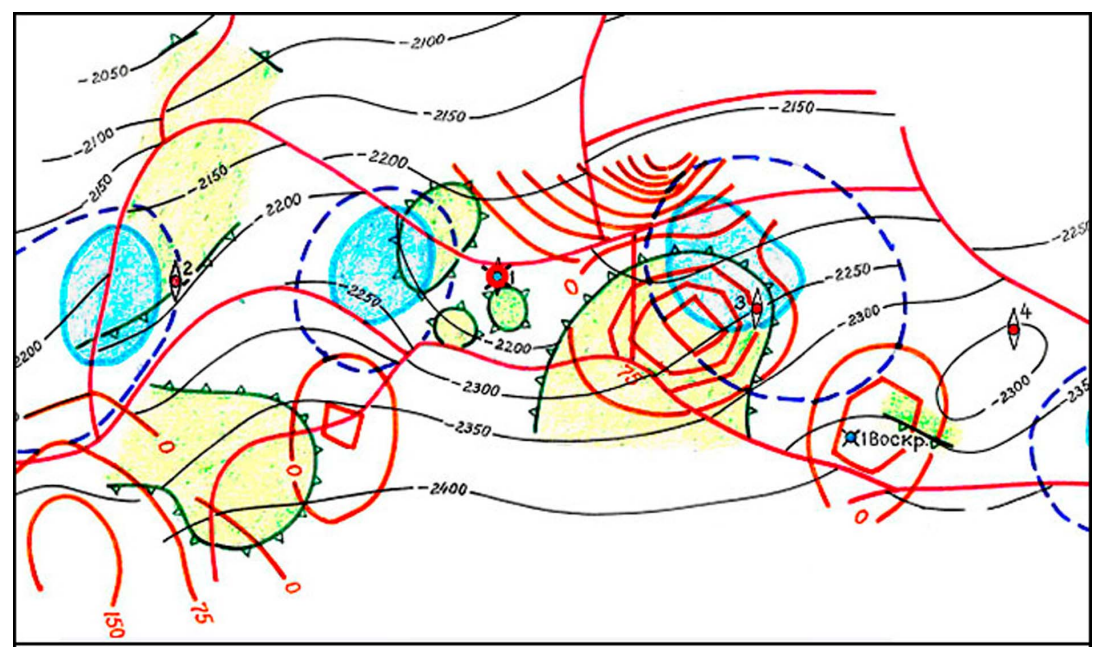

Fig. 3. Scheme of case study results on Kadnytska area (according to Arkhipov et al., 1999). Anomalies defined: using onland sensing methods (green line, 1), Eh, $\mathrm{pH}$ studies (red lines, 2), gas and geothemperature surveys (blue areas, 3). Small red circle is drilled dry well 1

the presence of hydrocarbon deposits was recorded, and the others results didn't confirm presence of hydrocarbons on the same facilities. As a logical follow up appears a request for decision making in favor of the results of only one of the techniques used and question: How to analyze the causes of ambiguity of research results?

\section{Geochemical methods}

A considerable number of techniques use the geochemical basis for the research of hydrocarbons, and there is a need to analyze the validity of geochemical forecasts made by different methods on objects of different types, that belong to certain tectonic zones, structures, a certain geological cross section, etc. Such targeted analysis should increase the accuracy of geochemical forecasting by applying different methodological techniques depending on the geological and tectonic features of the objects (Pererva et al., 1998).

\section{Remote sensing methods}

Due to the fact that seismic surveys are quite expensive and require thorough preparation, the quality of data obtained as a result of seismic surveys does not always correspond to what is necessary, that is related to errors in the processing of seismic source data and the conditions of the survey (large population on prospective areas, inaccessibility of some areas, etc). Remote sensing methods utilization helps to correct logistics of works, gives necessary information on the possible presence of annular structures and lineaments, which can serve as indicators of deep anticlines and faults, and in combination with other investigation methods, help to create structural models of objects.

The technology developed in CASRE based on the use of aerospace information and is designed to solve oil and gas exploration problems on land. Its application allows to allocate the most perspective sites for future detailed oil and gas exploration works. The technology is based on the quantitative assessment of the optical reflective characteristics of landscape elements and is the result of many years of joint work of petroleum geologists, optical physicists, biologists, geomorphologists, mathematicians and other specialists.

Thus, according to the remote sensing research data, a number of objects were predicted in Livnenska Area, which have high estimates as possible new hydrocarbon traps (Fig. 4).
According to the research results of CASRE IGN NAS of Ukraine specialists (Pererva et al., 1995, 1998) the greatest perspectives are related to neotectonic uplifts, which are defined to the North from the fault which divides Livinska fold (reflecting horizon Vv3) into two blocks - the northern one and the south one. To Northern block belong possible prospects of oil and gas. Within the neotectonic blocks \# 10, 11 and the northern part of block \# 14, were recorded optical anomalies, which partially coincide with the geochemical anomaly revealed by the case studies of other researchers (Bagriy, 2016).

Due to the absence of optical anomalies, the blocks 9, 12, 21 , the Northern parts of blocks 6, 7, the Northeast part of block 18 , and the Southern part of block 14 are classified as unpromising areas. In general, according to the results of detailed remote aerospace research, the authors conclude that the wells No 1, 3, 5, 7, 10 are in optimal conditions, and wells No 4, 6, 9 are not in optimal. However, there is also further ambiguity in the prediction of possible hydrocarbon traps within this area.

\section{Conclusions}

Summarizing all statements above it becomes clear that each type of study has its own advantages and known limitations. The need to obtain objects with a high probability of new fields discovery or expanding the area of already known fields by drilling exploration wells requires optimization and purposefulness of comprehensive implementation of case studies, geochemical and remote sensing methods. In order to create predictive structural-geological models based on the selected set of studies, use the latest software products with functionality to calculate predictive and prospective resources, using statistical probabilistic approaches and risk rates. In order to bring the scientific development closer to the production, it is advisable to restore not only geophysical prospect passports but also geological passports (new oil and gas "floors" at known fields, new structural elements that can be considered as hydrocarbon traps, new search areas).

\section{Acknowledgement}

We thank to Muzychko Tatiana (PJSC Ukrnafta) for consultancy during work on this article. 


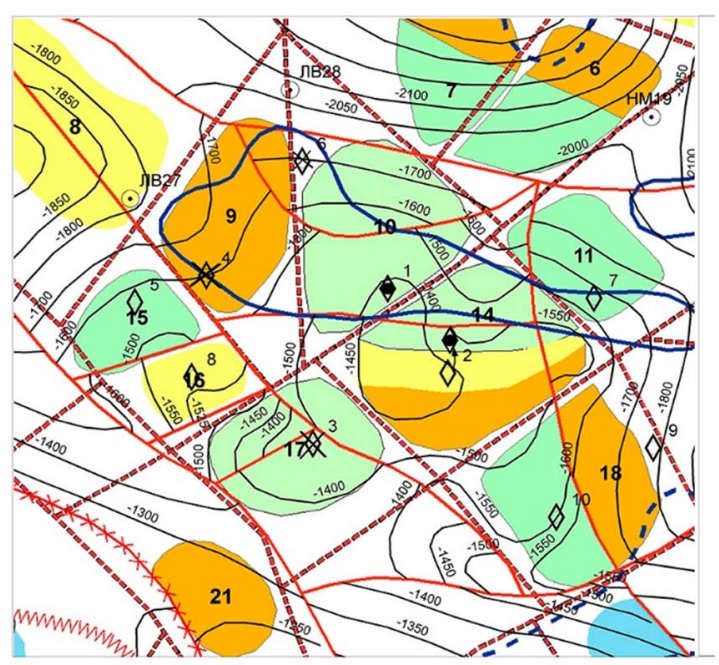

Fig. 4. Scheme of results of remote sensing studies on Livinska area (according to Arkhipov et al., 1999). Red lines — fault (regional and local), dotted red line - internal block lineaments and their zones, green areas — priority objects for seismic researches, blue areas - regions where additional studies are required, orange areas - non-perspective areas, yellow areas - zones above known deep prospective structures (according to Bagriy 2007)

\section{References}

Annual report of Naftogaz of Ukraine (Including affiliates) retrieved from http://www.naftogaz.com/www/3/nakweb.nsf/0/ 9B0566E71C6B0F9CC2257EDD006E558B?OpenDocument\&Expand=3\&.

Bagriy, I. D., Gladun, V. V., Gozhik, P. F., Krupsk, B. L., Klochko, V. P., Pochtarenko, V .I., Benko, V. M., Znamenska, T. O., Dubosarsky, V. R., Lihman, V. M., Chostak, T. A. (2007). Potential Oil and Gas Fields in Ukraina: Prediction of Potential Oil and Gas Fields in Dneeper-Donetsk Gas and Oil Area with the Implementation of the Integrated Set of Untraditional Near-Surface Research Methods. NAS of Ukraine, Institute of Geological science, Naftogaz of Ukraine. Kyiv. (in Ukrainian).

Bagriy, I. D., Karpenko, O. M., Dubosarskyi, V. R. (2016). Geological, structural, thermo-atmogeochemical technologies for forecasting, prospecting and exploration of hydrocarbon deposits. Manual. NAS of Ukraine, Institute of geological science, Geological institute of National Taras Shevchenko University. Kyiv. (in Ukrainian).

Gas Objects of OJSC Ukrnafta for 2008 and Beyond. (2008). Kyiv, TSGTD of OJSC Ukrnafta. (in Ukrainian).

Goshovsky, S. V, Lukin, O. Y., Prigarina, T. M., Demianenko, I. I., Polishchuk, M. B. (2007). Oil and gas potential of the Dnieper-Donets Basin and the strategy of development of exploration in the region. Zb. nauk. pr. Ukr. Derzg. Geologorozv. in-tu, 2, 16-21. (in Ukrainian).
Interactive map of prospects of Ukraine retrieved from http:// geoinf.kiev.ua/wp/interaktyvni-karty-spetsdozvoliv.htm/

Okrepka, T. S., Sokolov, L. V., Skuratovska, O. V., Shevshenko, M. V., Muzychko, I. I., Osadchuk, L., Muromtseva, O., Kolesova, O., Tkachenko, O. (2016). Comprehensive Study of the Results of Geological Exploration Work for 2015 and Determination of Priority Oil and Gas Objects of PJSC Ukrnafta for 2016 and Beyond. Kyiv. PJSC Ukrnafta. (in Ukrainian).

Pererva, V. M., Arkhipov, A. I., Busel, G. F., Okripky, R. M. (1998). Improving the efficiency of oil and gas exploration works. Naftova $i$ gazova promyslovist, 1. 6-10. (in Ukrainian).

Pererva, V. M., Lyalko, V. I., Arkhipov, A. I., Busel, G. F. (1995). Direct search of oil and gas reserves by remote methods (preliminary experience, prospects). Preprint CASRE of NASU. (in Russian).

Shybetska, T. I., Okrepka, T. S., Kardaeva, V. I., Sokolova, L. V., Shevchenko, M. B., Ivanuliak, A. M., Skuratovska, O. V. (2008). Comprehensive Study of the Results of Geological Exploration Work for 2007 and Determination of Priority Oil and Gas Exploration objects PJSC Ukrnafta for 2008 and beyond. Kyiv. CGTR PJSC Ukrnafta. (in Ukrainian).

Tovstyuk, Z. M. (1987). Forecast of local structures in remote airborne and space studies in the Dnieper-Donetsk Basin. (Unpublished candidate thesis). Kyiv department of the Institute of Geology and Fossil Fuels Development, Kyiv. (in Russian).

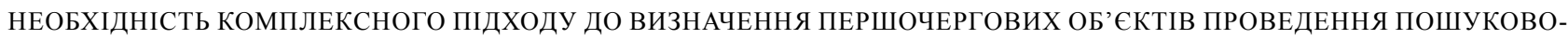
РОЗВІДУВАЛЬНИХ РОБІТ НА НАФТУ ТА ГАЗ

А. Г. Мичак, А. Ю. Шибецька

ДУ “Науковий центр аерокосмічних досліджень Землі ІГН НАН України”, вул. О. Гончара 55 Б, Київ 01054, Україна

ПАТ "Укрнафта" є основним підприємством України з видобутку нафти і веде пошуково-розвідувальне буріння в Дніпровсько-Донецькій западині та Прикарпатті. Скорочення об’ємів сейсморозвідувальних робіт негативно впливає на процес відкриття нових перспективних нафтогазоносниз структур. Достовірність та результативність сейсморозвідувальних робіт впливають на результативність пошуковорозвідувального буріння. В статті проаналізовано результати сейсморозвідувальних робіт, дані тематичних досліджень та геохімічної зйомки для прогнозування нафтогазоперспективності площ Дніпровсько-Донецької западини, а також їх комплексування. Показано, що об’єктивно зростає необхідність використання альтернативних методів розвідки, зокрема дистанційних методів визначення наявності вуглеводнів (з використанням космічних знімків). Для створення прогнозних структурно-геологічних моделей на основі вибраного набора досліджень в даний час широко використовуються новітні програмні продукти для розрахунку прогнозних та перспективних ресурсів $з$ використанням статистичних імовірнісних підходів та розрахунком рівня ризику. Комплексне вивчення результатів робіт проведених в минулі роки, використання сучасних методів та програмних комплексів для вивчення матеріалів дозволяє обгрунтовано визначати напрямки геологорозвідувальних робіт на наступні роки, підвищувати їх ефективність та зміцнювати національну сировинну базу.

Ключові слова: перспективні структури, геологорозвідувальні роботи, тематичні дослідження, комплексний підхід, дистанційне зондування, сейсморозвідка 
НЕОБХОДИМОСТЬ КОМПЛЕКСНОГО ПОДХОДА ДЛЯ ОПРЕДЕЛЕНИЯ ПЕРВООЧЕРЕДНЫХ ОБЪЕКТОВ ПРОВЕДЕНИЯ ПОИСКОВО-РАЗВЕДОЧНЫХ РАБОТ НА НЕФТЬ И ГАЗ

А. Г. Мычак, А. Ю. Шибецкая

ГУ “Научный центр аэрокосмических исследований Земли ИГН НАН Украины”, ул. О. Гончара 55 Б, Киев 01054, Украина

ПАО "Укрнафта" является основным предприятием Украины по добыче нефти и проводит поисково-разведочное бурение в ДнепровскоДонецкой впадине и в Прикарпатье. Сокращение объемов сейсморазведочных работ негативно влияет на процесс открытия новых перспективных нефтегазоносных структур. Достоверность и результативность сейсморазведочных работ влияет на результативность поисково-разведочного бурения. В статье проанализированы результаты сейсморазведочных работ, данные тематических исследований и геохимической съемки для прогнозирования нефтегазоперспективности площадей в Днепровско-Донецкой впадине, а также их комплексирование. Показано, что объективно возрастает необходимость использования альтернативных методов разведки, в частности дистанционных методов определения наличия углеводородов (с использованием космических снимков). Для создания прогнозных структурногеологических моделей на основе выбранного набора исследований в настоящее время широко применяются новейшие программные продукты с функциональными возможностями для расчета прогнозных и перспективных ресурсов с использованием статистических вероятностных подходов и расчетом уровней риска. Комплексное изучение результатов работ проведенных в предыдущие годы, использование современных методов и программных комплексов для изучения материалов позволяет обосновано определять направления геологоразведочных работ на следующие годы, повышать их эффективность и укреплять национальную сырьевую базу.

Ключевые слова: перспективные структуры, геологоразведочные работы, тематические исследования, комплексный подход, дистанционное зондирование, сейсморазведка

Рукопис статті отримано 12.06.2020 